Review

\title{
Lignin and Lignin-Derived Compounds for Wood Applications-A Review
}

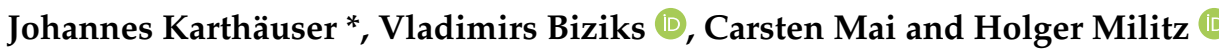 \\ Department of Wood Biology and Wood Products, Georg-August University of Goettingen, Büsgenweg 4, \\ 37077 Göttingen, Germany; vbiziks@gwdg.de (V.B.); cmai@gwdg.de (C.M.); hmilitz@gwdg.de (H.M.) \\ * Correspondence: Johannes.karthaeuser@uni-goettingen.de; Tel.: +49-551-39-19807
}

Citation: Karthäuser, J.; Biziks, V.; Mai, C.; Militz, H. Lignin and Lignin-Derived Compounds for Wood Applications-A Review. Molecules 2021, 26, 2533. https:// doi.org/10.3390/molecules26092533

Academic Editors: Eduardo Robles, Bertrand Charrier and

Grzegorz Kowaluk

Received: 30 March 2021

Accepted: 21 April 2021

Published: 26 April 2021

Publisher's Note: MDPI stays neutral with regard to jurisdictional claims in published maps and institutional affiliations.

Copyright: (c) 2021 by the authors. Licensee MDPI, Basel, Switzerland. This article is an open access article distributed under the terms and conditions of the Creative Commons Attribution (CC BY) license (https:// creativecommons.org/licenses/by/ $4.0 /)$.

\begin{abstract}
Improving the environmental performance of resins in wood treatment by using renewable chemicals has been a topic of interest for a long time. At the same time, lignin, the second most abundant biomass on earth, is produced in large scale as a side product and mainly used energetically. The use of lignin in wood adhesives or for wood modification has received a lot of scientific attention. Despite this, there are only few lignin-derived wood products commercially available. This review provides a summary of the research on lignin application in wood adhesives, as well as for wood modification. The research on the use of uncleaved lignin and of cleavage products of lignin is reviewed. Finally, the current state of the art of commercialization of lignin-derived wood products is presented.
\end{abstract}

Keywords: lignin; adhesive; LPF resins; wood modification

\section{Introduction}

Lignin is the most abundant aromatic polymer in nature and the second most abundant biomass on earth [1-3]. In paper production and other processes, lignin is obtained as a side product [4]. Over 50 million tons of lignin are currently annually produced as a side product in the paper industry alone. Additionally, the amount of isolated lignin produced is expected to increase [5]. Due to the recalcitrant, heterogeneous and complicated structure it is difficult to apply the thus-produced lignin, which is the reason why about $95 \%$ of it is burned to regain the inorganic chemicals necessary for the pulping process and to supply energy [6-8].

Because of the described situation and the phenolic-rich structure of the lignin, the conversion of technical lignin to higher-value products has been a topic of interest for many years. Despite major research and efforts, industrial applications of lignin are still only the exception $[9,10]$. Examples of the industrial usage of lignin are the production of vanillin or the addition of lignin to concrete, as well as dispersing and binding agents $[9,11]$. Additionally, several companies are selling purified lignin [12-14].

Due to the high phenolic content and the ability to form solid networks, the application of lignin for the treatment of wood is of interest. The phenolic structure of lignin leads to the idea of substituting phenol, which is conventionally won from non-renewable resources, in phenol-formaldehyde (PF) resins [15]. A lot of research has been conducted to implement lignin into the resins and to modify the lignin to improve its feasibility [16,17]. However, until now there are only a few companies that offer wood products based on lignin $[15,18]$. Hence, the research interest is still high, and potential applications are by now not only in the substitution for phenol in PF resins, but also in the substitution for urea in urea-formaldehyde (UF) and a broad range of other resins [3,19].

This review provides an overview on the state of the art of research on lignin in woodrelated applications, as well as on the implementation of lignin-based wood products in the industry. 


\section{Composition of Lignin}

The chemical structure of lignin varies significantly depending on the lignin source. Thus, upon considering lignin for any application, the characteristics of the different lignins have to be known, and the right type of lignin has to be carefully selected based on the target application.

Natural lignin is mainly built from three monomers, $\rho$-coumaryl alcohol (H-lignin unit), coniferyl alcohol (G-lignin unit) and sinapyl alcohol (S-lignin unit). The ratio between these monomers differs among lignins of different plant species and in different parts of the plants $[7,20]$. As such, the lignin in hardwood contains a higher quantity of S-lignin units, while softwood lignin contains more G-lignin units. H-lignin units are less abundant in wood, they can mainly be found in other plants $[21,22]$. The most common bond connecting the monomers in all natural lignins is the $\beta-O-4$ ether bond $[4,6]$. About $45-50 \%$ of the bonds in softwoods, and $60-62 \%$ in hardwoods are $\beta-O-4$ ether bonds [7].

For application in wood material treatment G- and H-lignin units and thus softwood or grass lignin is widely considered most promising. The reason for this can be found in the structure of the monomers; G- and H-lignin units have more reactive sites at the benzene ring, making them more reactive toward other binding material or chemical treatment [21,22]. Despite this, recent results have indicated that the lower molecular weight and other characteristics of hardwood lignin molecules might compensate for the lower number of reactive sites, thus producing lignin-phenol-formaldehyde (LPF) resins with similar characteristics. This topic is still under discussion, and a conclusion cannot be given [23-25].

Chemical extraction or treatment of lignin leads to even more variance between different lignins. In general, it was found that harsher treatment conditions lead to more significant changes of the structure, up to a point where the structure of these lignins, which are called technical lignins, does not have much in common with the structure of the naturally occurring lignin [7].

One of the most prominent examples of this is the Kraft process for production of chemical pulp. Due to high temperature and alkaline conditions, the structure of the lignin is dramatically changed during the process. The resulting Kraft lignin is a recalcitrant material, which is less reactive than natural lignin. Yet a lot of research on the usage of Kraft lignin has been carried out up to date $[7,26]$. However, there are also other important processes, during which lignin is extracted as a side product.

In the sulfide process, the lignocellulosic material is treated similarly to the Kraft process, but in an acidic medium. Lignins from the sulfide process are called lignosulfonates. They often have a higher molecular weight than Kraft lignin and are soluble in water due to the sulfonation at the $\alpha$-position [9]. Due to the high amount of active sulfonic acid groups lignosulfonates are suitable for various potential applications such as dispersants or emulsifiers [27].

Soda pulping is a pulping procedure during which no sulfur is used. It is the main pulping method for non-wood species. The main difference between soda pulping lignin and Kraft lignin is the lower sulfur content [2,9].

Because of the inert and recalcitrant structure of the aforementioned technical lignins, the "lignin-first" approach has received increasing attention. The idea of the approach is to cleave the lignin in a way that valuable products are gained. This could, for example, be achieved via solubilizing lignin with organic solvents [28]. Lignin that is cleaved from the lignocellulosic materials and dissolved by organic solvents is known as organosolv lignin. Usually, organosolv lignin is closer in structure to natural lignin, compared to other technical lignins [9]. However, this largely depends on the severity of the extraction. The solvent also plays a significant role in the yield and composition of the product $[29,30]$.

A more in-depth description on the different types and sources of lignin can be found elsewhere $[9,31]$. 


\section{Applications of Lignin in Wood}

Lignin is of interest for various applications in wood products. Most research has been carried out on the application of lignin as an adhesive. Adhesives are used for both solid wood and wood materials, as well as in engineered wood products such as fiberboards. For this application cleaving the lignin is not necessary because adhesives do not have to diffuse into the cell wall [32].

Cleaving the lignin is necessary for a different application, for which lignin-derived substances have high potential. Resins are commonly used for chemical wood modification. Chemical wood modification aims to improve important wood properties like dimensional stability, resistance to moisture, and bio-degradation, etc. To modify the wood, the modification material must enter the cell walls of the wood, and not just the wood lumen $[33,34]$. The cell walls can be entered from the lumen through micropores, which upon swelling have a maximum diameter of $2-4 \mathrm{~nm}$ in a water-saturated state [34]. Because of this diameter only smaller molecules can enter the cell walls $[35,36]$. As to be expected for a polymer, lignin molecules are too large for this. Because of this, lignin has to be cleaved for applications in chemical wood modification. Additional reasons for cleaving the lignin are the increase of reactive sites, a potential decrease of steric hindrance [37], as well as the potential production of other valuable chemicals, such as vanillin [8].

\section{Applying Lignin without Cleavage}

\subsection{General Remarks}

Considering the branched and stable structure of lignin, the most energy-efficient solution for applying lignin technically would be to apply it without cleavage. As mentioned before, lignin can be used without cleavage for adhesive applications.

Generally, lignin has a lower reactivity than monomers commercially used for resins. The reason for this is steric hindrance as well as additional substitutes on potential reactive sites and on the phenolic hydroxy group. The numbers of reactive sites for different lignins can, for example, be in the range of $0.81-1.72 \mathrm{mmol} \cdot \mathrm{g}^{-1}$, depending on the lignin source [38]. This results in longer pressing times or higher temperatures needed for the curing of the resins containing higher amounts of lignin [39]. Due to this, methods for pretreatment of lignin to improve the reactivity of the lignin and thus the energy efficiency are necessary.

\subsection{Application in PF Resins}

PF resins can be classified into resole-type and novolac-type PF resins. Resoles are formed under alkaline conditions and in excess of formaldehyde, while novolacs are formed under acidic conditions and in excess of phenol. While there are some publications on substituting phenol in novolacs with lignin [40-42], to the authors' knowledge, lignincontaining novolacs have not been applied in wood applications up to date.

\subsubsection{Methylolated Lignin in Resoles}

To improve the reactivity and thus the feasibility of lignin, various pretreatment methods are used [2,37]. An important method for pretreatment of lignin is methylolation. The aim of methylolation is to add functional hydroxymethyl groups to the lignin so that the lignin can directly react with the polymeric network of the resin. Herein, usually the reaction of formaldehyde with lignin under alkaline conditions is applied [37].

Kalami et al. (2017) managed to produce a resin made from methylolated lignin and formaldehyde, completely replacing the phenol. Timber joints produced with this adhesive exhibited shear lap strengths that were in accordance with the respective national requirements [43]. In a follow-up study, lignins from different sources were compared, showing that lignin containing more H- and G-lignin units are more suitable to replace phenol. The obtained resins performed only slightly worse than the PF resin, even with full replacement of phenol, while decreasing the formaldehyde consumption by up to $50 \%$ [22]. 
The formaldehyde emission of lignin-containing resins has to be examined with care in both PF and UF resins. Several publications reported higher formaldehyde emissions, due to the lower reactivity of the lignin compared to other monomers [44-46], while others reported similar or even lower formaldehyde emissions [47-50] upon replacing part of the phenol or urea monomers with lignin. This indicates that the formaldehyde emission is highly dependent on the ratio of monomers to formaldehyde, and on the reaction conditions.

Ghorbani et al. compared the influence of $20-40 \%$ of different types of technical lignins (organosolv, soda, Kraft and lignosulfonates) on PF resins. It was found that out of the given samples pine Kraft lignin and lignosulfonates were the most suitable lignins for replacing phenol. Beech veneer plywood produced with an LPF resin with $20-40 \%$ content of pine Kraft lignin even surpassed the tensile shear strength and wet tensile shear strength of PF resin. However, a higher curing temperature was applied to obtain these good properties [21,51]. In a follow-up study, LPF with $40 \%$ pine Kraft lignin was applied as an adhesive for beech plywood. The shear strength of the plywood was significantly lower than that of the PF, however, the plywood was suitable for exterior applications according to EN 314-1 [18]. Similarly, another publication reported that at 50\% replacement of phenol by Kraft lignin the shear strength and especially the wet shear strength of plywood produced with LPF were inferior to those with PF resin [52]. These results were contradicted by another study, in which up to 50\% Kraft lignin led to similar or even slightly improved performance compared to PF-bonded plywood [53]. Even higher substitution levels were reported by Abdelwahab et al. (2011), where up to $90 \%$ of phenol was substituted with Kraft lignin. The adhesives were tested according to ASTM D 2339-94A, and the adhesive strength was significantly higher for lignin-containing resins than for control PF resin, even at higher lignin concentrations [54].

In contrast to the results published by Ghorbani et al., Cheng et al. obtained very good results using organosolv lignin in a PF resin. Even at 75\% replacement of phenol by organosolv lignin extracted from pine saw dust, the shear strength and the wet shear strength of plywood produced with the LPF resin were higher than those of a reference PF resin [55]. The high potential of organosolv lignin was confirmed in another study, where up to $70 \%$ replacement of phenol by the organosolv lignin "Biolignin ${ }^{\mathrm{TM}}$ " by the company CIMV led to increased shear strengths compared to reference PF resin in plywood [56].

Eucalyptus plywood was produced with PF resin in which phenol was substituted with 5-25\% enzymatic hydrolysis lignin from cornstalk residues from bio-ethanol production extracted with sodium hydroxide solution. The plywood almost met the requirements for first grade plywood according to the Chinese National Standard (GB/T 14732-2006). The best results were achieved with $10 \%$ phenol substitution [57]. Another study using enzymatic hydrolysis lignin indicated that in adhesives the substitution of up to $50 \%$ of the phenol is possible without inferior mechanical performance. A shear strength of $1.05 \mathrm{MPa}$ was reported for three-layered plywood at $10 \%$ substitution of phenol with lignin [58]. A similar shear strength was reported for plywood made with a resin of $25 \%$ phenol, $25 \%$ urea and 50\% unpurified bio-ethanol fermentation residues. Three-layer plywood bonded with this resin met the Chinese national standards according to GB/T 17657-1999 [59].

Another comparison between LPF made with different lignins indicated that alkalineextracted lignin was most suitable out of alkaline-extracted, Kraft, organosolv and enzymatic hydrolysis lignin, at a substitution rate for $20 \%$ phenol. Particle boards produced with Kraft lignin containing LPF were suitable for P6 applications according to DIN EN 312:201012; the particle boards produced with enzymatic hydrolysis lignin, alkaline-extracted lignin and organosolv lignin containing LPFs performed well enough for P5 applications [25]. In another study on particle boards with PF resins, it was reported that $20-30 \%$ of the phenol could be substituted with organosolv lignin without a significant effect on the properties of the particle board [60].

In a comparison between lignin separated from different biomasses, including sugar mill bagasse, coconut coir, eucalyptus bark, and coffee beans using sodium hydroxide 
on small scale, each of the tested lignins improved the mechanical performance of wood samples bonded with PF resin up to 50\% substitution tested according to IS 851:1978 [61].

\subsubsection{Other Pretreatment Methods for Lignin in Resoles}

Phenolation is the condensation of phenol and lignin, providing more reactive sites as well as cleavage of the ether bonds $[37,38]$. Plywood panels made with LPF with phenol substituted with $33 \%$ phenolated lignin and formaldehyde performed worse than plywood made with PF resin or plywood made with LPF resin with methylolated lignin [62].

The preparation of methylolated nanosized alkalilignin could be interesting for application in PF resins, since it can be done in mild conditions by acidic precipitation from ethylene glycol. Tests of the performance of plywood produced with nanolignin-PF resins indicated a higher bond strength and wet bond strength at similar or slightly lower formaldehyde emission compared to normal PF resins. The highest bond strengths and wet bond strengths were achieved at 30 and $40 \%$ substitution of phenol with nanolignin [48]. In another study 5 or $10 \%$ of nanosized and microsized alkali lignin was added to a PF resin, with the best properties being achieved with $5 \%$ nanolignin. The shear strength of wood lap joints with the resin could be increased from $8.7 \mathrm{MPa}$ (pure PF resin) to 10.9 $\mathrm{MPa}$ [63].

The modification of the pine wood Kraft lignin by Fenton-oxidation and Fentonoxidation with subsequent ammoxidation did not improve the performance of LPF resins as wood adhesives [64].

Substituting $30 \%$ of phenol with demethylated soda lignin in an LPF resin considerably decreased the performance of plywood produced with the resin. Only lignin demethylated with $\mathrm{Na}_{2} \mathrm{SO}_{3}$ could be promising for future applications [65].

\subsubsection{Comparison of Selected Examples}

For better comparison, selected examples of different PF resins, the wood sample and the mechanical properties measured for it are presented in Table 1.

Table 1. Resin composition, sample type, and mechanical properties of selected PF resins described in literature.

\begin{tabular}{|c|c|c|c|}
\hline $\begin{array}{c}\text { Phenol Substitution Levels in the } \\
\text { Resin }\end{array}$ & Wood Sample & Mechanical Properties & Reference \\
\hline $\begin{array}{l}20 \% \text { substitution with methylolated } \\
\text { organosolv lignin }\end{array}$ & Particle board & $\begin{array}{l}\text { Internal bond strength (IB) }=1.02 \mathrm{MPa} \text {, } \\
\text { Thickness swelling (TS) }(2 \mathrm{~h})=10.6 \%\end{array}$ & {$[60]$} \\
\hline PF resin with $5 \%$ nanolignin & Wood lap joints & Shear strength $=10.9 \mathrm{MPa}$ & [63] \\
\hline $\begin{array}{l}100 \% \text { substitution with methylolated } \\
\text { enzymatic hydrolysis lignin }\end{array}$ & Plywood & $\begin{array}{c}\text { Dry shear strength: } 3.4 \mathrm{MPa}(84 \% \text { wood } \\
\text { failure), wet shear strength: } 2.6 \mathrm{MPa}(73 \% \\
\text { wood failure) }\end{array}$ & [43] \\
\hline $\begin{array}{c}40 \% \text { phenolated sodium } \\
\text { lignosulfonates }\end{array}$ & Plywood & Shear strength $=5.6 \mathrm{MPa}$ & [51] \\
\hline $\begin{array}{l}\text { Lignin-Formaldehyde resins with } \\
\text { methylolated softwood Kraft lignin, } \\
\text { and corn stover enzymatic } \\
\text { hydrolysislignin }\end{array}$ & Plywood & $\begin{array}{c}\text { Enzymatic hydrolysis lignin: shear } \\
\text { strength = } 3.2 \mathrm{MPa}(75 \% \text { wood failure), } \\
\text { softwood Kraft lignin: shear strength = } \\
2.6 \mathrm{MPa}(41 \% \text { wood failure })\end{array}$ & [22] \\
\hline $\begin{array}{l}50 \% \text { replacement with methylolated } \\
\text { pine sawdust organosolv lignin }\end{array}$ & Plywood & $\begin{array}{l}\text { Tensile strength }=2.25 \mathrm{MPa}(93 \% \text { wood } \\
\text { failure }) \text {, tensile wet strength }=1.9 \mathrm{MPa} \\
\qquad(85 \% \text { wood failure })\end{array}$ & [55] \\
\hline PF resin with $30 \%$ nanolignin & Plywood & $\begin{array}{c}\text { Dry bond strength = } 1.59 \mathrm{MPa}(100 \% \\
\text { wood failure), wet bond strength = } \\
0.89 \mathrm{MPa}(100 \% \text { wood failure })\end{array}$ & [48] \\
\hline
\end{tabular}

\subsection{Application in UF Resins}

Because of the similarity in structure, the application of lignin in PF resins is the first that comes to mind; however, lignin can also form bonds with other resins. The most prominent example of this is the formation of lignin-urea-formaldehyde (LUF) resins, because UF is the most produced adhesive for wood applications worldwide [66]. 
Addition of up to $20 \%$ of phenolated Kraft lignin only slightly decreased the internal bond strength of a UF resin in a particle board while significantly lowering the formaldehyde emission of the board [47].

Lignin can be pretreated with ionic liquids, which separates the lignin from lignocellulosic biomass. Treatment with ionic liquids decreases the quantity of methoxy-groups, thus increasing the reactivity of lignin [1]. Replacing urea in UF resins by soda bagasse black liquor treated with ionic liquids led to a decrease in shear strength and wood failure in plywood. The decrease in shear strength and wood failure was less pronounced than for samples with the same amount of untreated black liquor, confirming the increase of reactivity [67]. In a follow-up study, the performance of the LUF resins could be improved by the addition of $6 \%$ of the resin weight of polymeric diphenylmethane diisocyanate (PDMI). However, a direct comparison to UF resin was not described [68].

Another pretreatment method for the application of lignin in UF resins was recently presented by Gao et al. (2020) [49] for the application as an additive in plywood and medium-density fiberboards (MDFs). Methylolated lignin was esterified with maleic anhydride. The addition of $5 \%$ of maleic anhydride-treated lignin to a UF resin for plywood applications performed comparatively as well as plywood treated with reference UF resin while additionally decreasing the water absorption of the plywood [49].

The storage time of UF resin could be increased from $30 \mathrm{~d}$ to $200 \mathrm{~d}$ with addition of $20 \%$ methylolated sodium lignosulfonate. The formaldehyde emission and shear strength of eucalyptus plywood cured with the modified resin only slightly changed compared to pure UF resin. However, at $60 \%$ substitution, the properties were significantly worse [46].

For better comparison, selected examples of different UF resins, the wood sample and the mechanical properties measured for it are presented in Table 2.

Table 2. Resin composition, sample type, and mechanical properties of selected UF resins described in literature.

\begin{tabular}{|c|c|c|c|}
\hline Urea Substitution Levels in the Resin & Wood Sample & Mechanical Properties & Reference \\
\hline $\begin{array}{c}10 \% \text { ionic liquid pretreated soda } \\
\text { bagasse lignin }\end{array}$ & Plywood & shear strength $=1.89 \mathrm{MPa}$, wood failure $=70 \%$ & [67] \\
\hline $5 \%$ lignin-based polyacid catalyst & Plywood and MDF & $\begin{array}{c}\text { Plywood: shear strength }=1.72 \mathrm{MPa} \text {, wet shear } \\
\text { strength }=1.2 \mathrm{MPa} \\
\text { MDF: IB }=1.35 \mathrm{MPa}, 24 \mathrm{~h} \mathrm{TS}=9 \%\end{array}$ & [49] \\
\hline $\begin{array}{l}\text { 15\% ionic-liquid-treated soda bagasse } \\
\text { lignin with } 6 \% \text { PMDI additive }\end{array}$ & Plywood & $\begin{array}{c}\text { Dry shear strength }=2.2 \mathrm{MPa}(100 \% \text { wood } \\
\text { failure), wet shear strength }=0.99 \mathrm{MPa}(70 \% \\
\text { wood failure }), \text { water adsorption }=22 \%\end{array}$ & [68] \\
\hline
\end{tabular}

\subsection{Application in Other Resins}

Glyoxal was used to synthesize a formaldehyde-free lignin-urea-glyoxal (LUG) resin. The mechanical properties and the water resistance of the LUG resin were worse than those of resins with formaldehyde; however, they could be improved by adding nanoclay or epoxy resin. The best results were achieved with $5 \%$ of the weight of the resin addition of epoxy resin. The wood failure in dry shear strength tests was $100 \%$ at $1.7 \mathrm{MPa}$, the wet shear strength was 1.3 MPa with 80\% wood failure [69,70]. Additionally, research on the use of glyoxal in lignin-phenol-glyoxal (LPG) resin with black liquor from soda bagasse in particle boards was done. The particle boards performance was inferior to a reference PF resin; however, the requirements for the related EN-standards were still fulfilled [71]. In a follow-up study, the performance of the resin was improved by adding $7 \%$ of the resins' weight of epoxy resin. Plywood bonded with this resin had shear strength, wet shear strength and water absorption comparable to plywood produced with reference PF resin [72].

Another approach was proposed by Zhang et al. (2019) [10], who described a ligninfurfuryl-glyoxal adhesive. Adding up to $9 \%$ of the resins' weight of epoxy resin to improve the water resistance, the adhesive was used for beech wood particle boards. While the internal bond (IB) strength, the wet IB strength and the curing time of the particle boards were 
worse than with a commercial PF resin, they still met the Chinese regulation requirements according to GB/T17657(2006) [10].

A method to increase the water resistance of LPF resins is to add furfural. Resins made with $50 \%$ phenol replacement by Kraft lignin and $15 \%$ addition of furfural were used to produce plywood. The mechanical properties were similar to plywood produced with reference PF resin [73].

Another field is the use of lignin in polyurethane adhesives. Lignin can improve the mechanical performance of polyurethanes when used as a polyol. Enhancing this effect even further can be achieved by using demethylated lignin. A total of $20 \%$ of polyethylenglycol in a polyurethane system with toluol-diisocyanate was replaced by the lignin. A tensile strength of 91.2 MPa was reported for the adhesives binding single aspen wood chips according to GB/T 9846-2015 [74]. A self-healing, recoverable polyurethane adhesive with $20 \%$ lignin modified with long chain polyetheramines was presented by Liu et al. (2020) [75]. The polyurethane adhesives all showed improved lap shear strengths upon addition of lignin or modified lignin, the best value being a lap shear strength of $7.8 \mathrm{MPa}$ for beech wood boards in the first test (upon reusing, even higher values were achieved) [75].

Ammonium lignosulfonate treated with $\mathrm{H}_{2} \mathrm{O}_{2}$ and blended with polyethyleneimine was used as a binder in the production of MDF. Under optimal conditions $\left(170{ }^{\circ} \mathrm{C}\right.$ hot pressing temperature, 7 minutes pressing time, $20 \%$ binder content), the Chinese requirements for mechanical properties of MDF were met [76].

Other pretreatment methods and observations that were described in literature will be mentioned briefly below. Oxidation of lignin by laccase increases the reactivity [77]. Solvent fractioning can be used to obtain higher and lower molecular weight fractions from Kraft lignin. The results indicated that the mechanical properties of a cured LPF resin are not significantly influenced by the molecular weight of the lignin [15]. The reactivity of fractionated Kraft lignin can be improved by phenolation. However, plywood produced with an LPF resin with $40 \%$ phenolated Kraft lignin fractionated by solubilization in different solvents was inferior to plywood produced with PF resin for all fractions. Despite this, the properties of the plywood met the Chinese national standards GB/T14732 [44]. Lignin can function as a fire retardant and photo stabilizer in epoxy resins [78,79].

Selected examples for different resins as well as their mechanical properties are listed in Table 3.

Table 3. Resin composition, sample type, and mechanical properties of selected resins on different basis than PF and UF described in literature.

\begin{tabular}{|c|c|c|c|}
\hline Resin Composition & Wood Sample & Mechanical Properties & Reference \\
\hline $\begin{array}{c}\text { LPG resin with } 20 \% \text { soda bagasse black } \\
\text { liquor }\end{array}$ & Particle board & $\begin{array}{c}\mathrm{IB}=0.6 \mathrm{MPa}, \text { water absorption }=14 \% \\
\text { thickness swelling }=10 \%\end{array}$ & {$[71]$} \\
\hline $\begin{array}{l}\text { LPG resin with } 30 \% \text { bagasse soda black } \\
\text { liquor and } 7 \% \text { epoxy resin }\end{array}$ & Plywood & $\begin{array}{l}\text { Dry shear strength }=1.74 \mathrm{MPa}(100 \% \text { wood } \\
\text { failure); wet shear strength }=1.0 \mathrm{MPa}(80 \% \\
\text { wood failure), thickness swelling }=4 \%\end{array}$ & {$[72]$} \\
\hline $\begin{array}{l}\text { LUG resin with } 15 \% \text { glyoxalated bagasse } \\
\text { soda black liquor and 5\% epoxy resin }\end{array}$ & Plywood & $\begin{array}{c}\text { Dry shear strength }=1.7 \mathrm{MPa}(100 \% \text { wood } \\
\text { failure), Wet shear strength }=1.3 \mathrm{MPa}(80 \% \\
\text { wood failure), Water absorption }=6 \%\end{array}$ & [70] \\
\hline $\begin{array}{l}\text { Polyurea adhesive doped with } 20 \% \\
\text { polyetheramine chain grafted lignin with } \\
\text { functional disulfide bonds }\end{array}$ & $\begin{array}{l}\text { Beech wood } \\
\text { boards }\end{array}$ & Lap shear strength $=7.8 \mathrm{MPa}$ & [75] \\
\hline
\end{tabular}

\section{Cleavage of Lignin}

\subsection{General Remarks}

Most publications on lignin in wood applications deal with uncleaved lignin. However, for wood modification, the cleavage of lignin is inevitable. Hence, the cleavage of lignin and applications of products thereof will be described. 


\subsection{Characterization of Cleavage Products}

There are various ways to cleave lignin, e.g., hydrolysis, pyrolysis, liquefaction, etc. However, in most lignin depolymerization methods, the main products are phenolic compounds such as phenol, catechol, guaiacol, ortho- and para-cresol, etc. [80,81]. A screening of the combability of these monomers with PF-resols was done by Biziks et al. (2020) [80]. Herein, it was reported that guaiacol, o-, m-, p-cresol, and 4-ethylphenol were suitable for phenol replacement, whereas catechol, 4-methylguaiacol, and syringol had negative impacts on the performance of the resin. Bio-oils obtained by cleaving lignin contain many compounds that are suitable for substitution of phenol in PF resins. However, due to the complex mixture it is often not possible to obtain a bio-oil that does not also contain molecules that worsen the resins' characteristics [80].

Dier et al. (2017) [82] tested the influence of model bio-oils with different ratios of monomers on the characteristics of the resols. As in the study by Biziks et al. (2020), it was found that bio-oils that contain cresols have high potential to replace phenol in PF resins, while catechols negatively impacted the properties of the resin [82].

\subsection{Cleavage of Lignin}

In literature, pyrolysis is the most described method for biomass cleavage. However, despite the great amount of research, the application of pyrolysis oil of lignin for wood applications has received little attention. A reason for this could be that, considering the current price for lignin, the on-site production of bio-oils from technical lignin is in most cases not economically feasible, as was shown in a study by Farag et al. [83]. An LPF resin with $0-100 \%$ phenol substitution with wheat straw lignin depolymerized by alkali-catalyzed microwave digestion was prepared. The bonding strength of a plywood was higher with $40 \%$ substitution than for reference PF resin, and it was similar even at $80 \%$ substitution [84].

Organosolv lignin from pine sawdust cleaved in hot water/ethanol under high pressure and hydrogen atmosphere with metallic salt-catalyst-produced monomers, which were used to replace up to $75 \%$ of phenol in a PF resin. At both 50 and $75 \%$ replacement, the wet and dry shear strength of plywood bonded with the resin could be improved, while only at $75 \%$ replacement the moisture resistance decreased. The mechanical properties were, however, not better than those reported for a PF resin with non-degraded organosolv lignin prepared by the same method [55].

Amounts of $50-70 \%$ of phenol in a PF resin were replaced by base-catalyzed depolymerized pine Kraft lignin. The longitudinal tensile shear strength of wood joints produced with the resin was similar to or higher than that of the reference PF resin. The best results were achieved with 70\% replacement of phenol [85].

Resins made from different lignins liquefied with phenol and inorganic acid catalysts were tested for application in PF resins. The highest dry and wet shear strengths were achieved with alkaline lignin, $\mathrm{HCl}$ as a catalyst, and with a phenol replacement of $40 \%$. The mechanical properties were similar to those of commercial PF resin, with an increased F emission. Lauan plywood produced this way had a tensile shear strength of $1.42 \mathrm{MPa}$ and a warm-water-soaked binding strength of 1.22 MPa [45].

Selected examples of resins containing cleaved lignin products and their mechanical properties are listed in Table 4.

\subsection{Cleavage of Lignocellulosic Biomass}

Upon producing bio-oil from natural lignin, the lignin is often not separated from the lignocellulosic material, as this would be an additional energy-consuming work step. Instead, the biomass is often directly treated. However, because this review focuses mainly on separated lignin, the cleavage and usage of lignocellulosic biomass will only be briefly discussed. In literature, the water-insoluble part of bio-oils derived from biomass are often referred to as "pyrolytic lignin", as they mainly contain lignin-derived compounds and thus resemble lignin pyrolysis oil well [86]. 
Table 4. Resin composition, sample type, and mechanical properties of selected resins with cleaved lignin described in literature.

\begin{tabular}{cccc}
\hline Resin Composition & Wood Sample & Mechanical Properties & Reference \\
\hline $\begin{array}{c}\text { PF resin with 70\% oligomer lignin from pine } \\
\text { Kraft lignin treated by base-catalyzed } \\
\text { depolymerization }\end{array}$ & Beech lamellas & $\begin{array}{c}\text { Tensile shear strength = 15 MPa. Wet tensile } \\
\text { shear strength about 6 MPa }\end{array}$ \\
$\begin{array}{c}\text { PF resin with 40\% alkaline-catalyzed } \\
\text { microwave-digested wheat straw lignin }\end{array}$ & Plywood & $\begin{array}{c}\text { Bonding strength }=1.70 \mathrm{MPa} \\
\text { [85] }\end{array}$ & $\begin{array}{c}\text { Dry bonding strength }=1.42 \mathrm{MPa} \text {, warm } \\
\text { water soaking bonding strength }=1.22 \mathrm{MPa}, \\
\text { repetitive boiling water soaking bonding } \\
\text { strength }=1.10 \mathrm{MPa}\end{array}$ \\
\hline
\end{tabular}

In a patent formulated in 1999, pyrolysis oil of wood bark, a side product in forestry, was substituted for $40 \%$ of the phenol in PF resins for oriented strand boards. The internal bonding and the torsion shear strength increased compared to a commercial PF resin [87]. Similarly, $30 \%$ of phenol was replaced by pyrolysis oil of wood bark in another study. The properties of oriented strand board (OSB) with this resole, produced with standard procedures commonly used in industry, met the Canadian standards CSA (0437.1-93) [88]. In another study, $40-50 \%$ of phenol in a PF was replaced by pyrolysis oil from pure wood or bark for plywood and OSB production. Similar or better performance compared to plywood and OSB with control PF resin was achieved under industrially common production conditions and at larger scale production [81].

Pyrolysis of wood residues has the problem of there being additional pyrolysis products from cellulose and hemicelluloses that do not react in the resin and thus might weaken it $[89,90]$. Hence, distillation and purification of the fast pyrolysis products of wood wastes with the organic solvents hexane or benzene can significantly improve the water resistivity of the resin. For an LPF resin with $40 \%$ substitution of phenol, both a dry and a wet shear strength of about 3.25 MPa were measured in wood glue line tests [89]. Separating the fast pyrolysis products by water and methanol extraction produced a pyrolytic lignin that could replace up to $40 \%$ of the phenol in PF resin for the application in OSB. At $30 \%$ substitution, the bio-oil containing OSB had comparable modulus of rupture (MOR), modulus of elasticity (MOE), TS, water absorption and dry or wet internal bond strengths to the reference OSB with PF resin [90].

Celikbag et al. [91] replaced different amounts of phenol in a PF resin with bio-oil from hydrothermal liquefaction of sweetgum wood chips without bark. The bonding strength of the obtained resin tested on thin wood stripes increased from 6.3 $\mathrm{MPa}$ (PF resin) to $7.8 \mathrm{MPa}$ for PF resin with about $75 \%$ of phenol replaced by the bio-oil [91].

Applying the cleaved products of biomass as a whole in wood applications has received far more attention than those of lignin specifically. This shows a potential lack of research on the application of lignin cleavage products in wood applications. Future research in this field could lead to important new insights and discoveries.

\section{Challenges for the Application of Lignin and Lignin-Derived Compounds}

The high amount of research indicates the interest in the valorization of lignin; however, commercial applications have been limited up to date. Reasons for this are different challenges that have to be met. The low reactivity of lignin is a challenge that can be overcome by lignin modification or cleavage, but also by higher curing temperatures, pressing time or accelerators $[37,39]$. However, further chemical modification increases the cost of lignin utilization. This is especially a problem because several reports have indicated that currently the utilization of lignin is not economically feasible [83,92,93]. Another challenge is the heterogeneity of lignin, due to which lignin often shows unexpected behavior $[8,27]$. Technical lignins obtained from different plant species have different properties, and different ratios, for example, in black liquor, can lead to varying quality in the final application [22,23]. An answer to that challenge might be lignin fractionation or cleav- 
age $[15,44]$. In the field of wood modification the size of the lignin molecules is problematic, as only small molecules can enter the cell wall [34-36]. Methods for lignin cleavage to use lignin for such applications are underway. However, not all lignin cleavage products are suitable for the substitution of monomers commonly used in wood modification [80,81].

\section{Current or Past Commercial Products of Lignin-Based Adhesives in Wood Industry}

As mentioned before, industrial commercial products of lignin have been limited up to date. Until now, lignin has only been sold as an adhesive; products for wood modification are, to the authors' knowledge, not commercialized. Nevertheless, there are some examples of companies who have offered or are offering lignin-based wood products.

In the past, particle boards and fiberboards with an LPF resin containing 25\% lignin were produced by the company VEB Plasta Erkner (today Prefere Resins Holding GmbH). The production of these products was stopped in 1990 because the black liquor used as the lignin source could not be provided anymore, and substituent lignin sources performed worse [94,95]. However, the company did not lose interest in lignin, and in 2017 the production of LPF resin with 50\% lignin was started, and fiberboards as well as other wood-based materials treated with the resin are on the market [95]. Interestingly, in the same year also the company UPM Biochemicals commercialized an LPF product. UPM BioPiva $^{\mathrm{TM}}$ allows to replace $80 \%$ of phenol for the production of plywood and other wood products [96]. Stora Enso is another company that offers lignin products. Their Lineo ${ }^{\mathrm{TM}}$ Kraft lignin is, as they advertise, suitable for replacing phenols in resins for plywood, oriented strand board and laminated veneer lumber [12]. Lignins as a replacement for resins in fiberboards are also offered by Lignotech, a company owned by Borregaard [97]. The French company CIMV provides the organosolv lignin "Biolignin ${ }^{\mathrm{TM}}$ ", which performs well as an adhesive for plywood with replacement of up to $70 \%$ of phenol in PF resin [13,56]. There are several companies that are offering or currently implementing further ligninbased products for wood treatment [14,98-100].

These examples show that the commercial application of lignin as an adhesive for wood is on the rise. This indicates that the research on lignin is, at least in this area, close to the needs of industry. This was confirmed by an importance performance analysis, wherein the majority of experts from industry and research stated that the research on lignin application in PF resins is promising in the most relevant aspects [101]. The rising commercial interest as well as the rising lignin price and lignin market further underline this $[93,102]$.

Additional indications of high commercial interest in lignin applications are patents. There are several patents describing resins containing lignin [87,103-109]. However, most of the patents mentioned herein were assigned a long time ago, so implications for the recent interest in lignin cannot be derived from them.

Until now, there are only a few life cycle assessment studies on lignin-derived wood products [3]. This can be a problem, as in some cases the new products have a similar or even slightly worse sustainability compared to classical solutions [110]. However, in the majority of the studies the results have indicated that the substitution of resin monomers with lignin improves the sustainability of wood products [110-112].

\section{Conclusions}

Up to date, there have only been few examples of the commercial application of lignin as an adhesive and none for the application of lignin for wood modification. In contrast, in the scientific field there are many reports on lignin application as an adhesive, and several reports on the use of lignin in wood modification. While many of the herein proposed ligninbased products fail to achieve the same mechanical properties as commercial resins or are not commercially feasible, there is still a discrepancy between the theoretical knowledge and the practical applications. A large variety of promising methods and approaches have been presented, and the number of recent publications shows that the scientific interest and ability to introduce new ideas is still high. Additionally, several studies 
have suggested that the substitution of commercial monomers with lignin would have environmental benefits [110-112]. However, in some publications it has been stated that currently, due to the low phenol prices, the use of lignin is not economically feasible [92,93]. The bottleneck could be the transition from laboratory to industrial scale. To improve this, more communication and projects combining science and industry are necessary. The rising number of companies that are developing new lignin-based methods or products indicates that this process is already happening. Hence, there is a likelihood that lignin will in the future fulfill its potential to a higher degree.

Author Contributions: Writing—original draft preparation, J.K.; writing—review and editing, V.B., C.M. and H.M. All authors have read and agreed to the published version of the manuscript.

Funding: This research received no external funding.

Acknowledgments: We acknowledge support by the Open Access Publication Funds of the Göttingen University.

Conflicts of Interest: The authors declare no conflict of interest.

\section{References}

1. Qu, Y.; Luo, H.; Li, H.; Xu, J. Comparison on Structural Modification of Industrial Lignin by Wet Ball Milling and Ionic Liquid Pretreatment. Biotechnol. Rep. 2015, 6, 1-7. [CrossRef]

2. Wang, Y.-Y.; Meng, X.; Pu, Y.J.; Ragauskas, A. Recent Advances in the Application of Functionalized Lignin in Value-Added Polymeric Materials. Polymers 2020, 12, 2277. [CrossRef] [PubMed]

3. Bajwa, D.S.; Pourhashem, G.; Ullah, A.H.; Bajwa, S.G. A Concise Review of Current Lignin Production, Applications, Products and Their Environmental Impact. Ind. Crop. Prod. 2019, 139, 111526. [CrossRef]

4. Chakar, F.S.; Ragauskas, A.J. Review of Current and Future Softwood Kraft Lignin Process Chemistry. Ind. Crop. Prod. 2004, 20, 131-141. [CrossRef]

5. Luo, H.; Abu-Omar, M.M. Chemicals from Lignin. In Encyclopedia of Sustainable Technologies; Elsevier: Amsterdam, The Netherlands, 2017; pp. 573-585. ISBN 978-0-12-804792-7.

6. Wang, Y.; Wang, Q.; He, J.; Zhang, Y. Highly Effective C-C Bond Cleavage of Lignin Model Compounds. Green Chem. 2017, 19, 3135-3141. [CrossRef]

7. Rinaldi, R.; Jastrzebski, R.; Clough, M.T.; Ralph, J.; Kennema, M.; Bruijnincx, P.C.A.; Weckhuysen, B.M. Paving the Way for Lignin Valorisation: Recent Advances in Bioengineering, Biorefining and Catalysis. Angew. Chem. Int. Ed. 2016, 55, 8164-8215. [CrossRef]

8. De Wild, P.J.; Huijgen, W.J.J.; Gosselink, R.J.A. Lignin Pyrolysis for Profitable Lignocellulosic Biorefineries. Biofuels Bioprod. Bioref. 2014, 8, 645-657. [CrossRef]

9. Kai, D.; Tan, M.J.; Chee, P.L.; Chua, Y.K.; Yap, Y.L.; Loh, X.J. Towards Lignin-Based Functional Materials in a Sustainable World. Green Chem. 2016, 18, 1175-1200. [CrossRef]

10. Zhang, J.; Wang, W.; Zhou, X.; Liang, J.; Du, G.; Wu, Z. Lignin-Based Adhesive Crosslinked by Furfuryl Alcohol-Glyoxal and Epoxy Resins. Nord. Pulp. Pap. Res. J. 2019, 34, 228-238. [CrossRef]

11. Evstigneyev, E.I.; Shevchenko, S.M. Lignin Valorization and Cleavage of Arylether Bonds in Chemical Processing of Wood: A Mini-Review. Wood Sci. Technol. 2020, 54, 787-820. [CrossRef]

12. Stora Enso OYJ. LineoTM by Stora Enso Nominated for "Bio-Based Material of the Year 2019" Innovation Award. Available online: https:/ / www.storaenso.com/en/newsroom/news/2019/5/lineotm-award-nomination (accessed on 16 March 2021).

13. CIMV Biolignin @. Available online: http://www.cimv.fr/products/11-.html?lang=en (accessed on 16 March 2021).

14. Suzano, S.A. Suzano-Lignin. Available online: https://www.suzano.com.br/en/brands-and-products/lignin/ (accessed on 19 March 2021).

15. Solt, P.; Jaaskelainen, A.-S.; Lingenfelter, P.; Konnerth, J. Impact of Molecular Weight of Kraft Lignin on Adhesive Performance of Lignin-Based Phenol-Formaldehyde Resins. For. Prod. J. 2018, 68, 7. [CrossRef]

16. Paananen, H.; Pakkanen, T.T. Kraft Lignin Reaction with Paraformaldehyde. Holzforschung 2020, 74, 663-672. [CrossRef]

17. Kim, J.-S. Production, Separation and Applications of Phenolic-Rich Bio-Oil-A Review. Bioresour. Technol. 2015, 178, 90-98. [CrossRef]

18. Ghorbani, M.; Liebner, F.; van Herwijnen, H.W.G.; Solt, P.; Konnerth, J. Ligneous Resole Adhesives for Exterior-Grade Plywood. Eur. J. Wood Prod. 2018, 76, 251-258. [CrossRef]

19. Lora, J.H.; Glasser, W.G. Recent Industrial Applications of Lignin: A Sustainable Alternative to Nonrenewable Materials. J. Polym. Environ. 2002, 10, 39-48. [CrossRef]

20. Fengel, D.; Wegener, G. Wood: Chemistry, Ultrastructure, Reactions, Reprint der Orig.-Ausg. (ehem. de Gruyter); Kessel: Remagen, Germany, 2003; ISBN 978-3-935638-39-5.

21. Ghorbani, M.; Liebner, F.; Van Herwijnen, H.W.G.; Pfungen, L.; Krahofer, M.; Budjav, E.; Konnerth, J. Lignin Phenol Formaldehyde Resoles: The Impact of Lignin Type on Adhesive Properties. Bioresources 2016, 11, 6727-6741. [CrossRef] 
22. Kalami, S.; Chen, N.; Borazjani, H.; Nejad, M. Comparative Analysis of Different Lignins as Phenol Replacement in Phenolic Adhesive Formulations. Ind. Crop. Prod. 2018, 125, 520-528. [CrossRef]

23. Lourençon, T.V.; Alakurtti, S.; Virtanen, T.; Jääskeläinen, A.-S.; Liitiä, T.; Hughes, M.; Magalhães, W.L.E.; Muniz, G.I.B.; Tamminen, T. Phenol-Formaldehyde Resins with Suitable Bonding Strength Synthesized from "Less-Reactive" Hardwood Lignin Fractions. Holzforschung 2020, 74, 175-183. [CrossRef]

24. Balakshin, M.; Capanema, E. Rethinking Biorefinery Lignins: Breaking Dogmas. In Proceedings of the 14th European Workshop on Lignocellulosics and Pulp; Grenoble INP, Autrans, France, 28 June-1 July 2016.

25. Stücker, A.; Schütt, F.; Saake, B.; Lehnen, R. Lignins from Enzymatic Hydrolysis and Alkaline Extraction of Steam Refined Poplar Wood: Utilization in Lignin-Phenol-Formaldehyde Resins. Ind. Crop. Prod. 2016, 85, 300-308. [CrossRef]

26. Crestini, C.; Lange, H.; Sette, M.; Argyropoulos, D.S. On the Structure of Softwood Kraft Lignin. Green Chem. 2017, 19, 4104-4121. [CrossRef]

27. Vishtal, A.; Kraslawski, A. Challenges in Industrial Applications of Technical Lignins. Bioresources 2011, 6, 3547-3568. [CrossRef]

28. Paone, E.; Tabanelli, T.; Mauriello, F. The Rise of Lignin Biorefinery. Curr. Opin. Green Sustain. Chem. 2020, 24, 1-6. [CrossRef]

29. Luo, H.; Abu-Omar, M.M. Lignin Extraction and Catalytic Upgrading from Genetically Modified Poplar. Green Chem. 2018, 20, 745-753. [CrossRef]

30. Jiménez-López, L. Co-Production of Soluble Sugars and Lignin from Short Rotation White Poplar and Black Locust Crops. Wood Sci. Technol. 2020, 27, 1617-1643. [CrossRef]

31. Liao, J.J.; Latif, N.H.A.; Trache, D.; Brosse, N.; Hussin, M.H. Current Advancement on the Isolation, Characterization and Application of Lignin. Int. J. Biol. Macromol. 2020, 162, 985-1024. [CrossRef]

32. Rowell, R.M. Handbook of Wood Chemistry and Wood Composites; CRC Press: Boca Raton, FL, USA, 2005; ISBN 978-0-8493-1588-6.

33. Bicke, S.; Militz, H. Modification of Beech Veneers with Low Molecular Weight Phenol Formaldehyde for the Production of Plywood: Comparison of the Submersion and Vacuum Impregnation; Laboratório Nacional Deengenharia Civil: Lisbon, Portugal, 2014.

34. Hill, C.A.S. Wood Modification: Chemical, Thermal and Other Processes; Wiley Series in Renewable Resources; John Wiley \& Sons: Chichester, UK; Hoboken, NJ, USA, 2006; ISBN 978-0-470-02172-9.

35. Furuno, T.; Imamura, Y.; Kajita, H. The Modification of Wood by Treatment with Low Molecular Weight Phenol-Formaldehyde Resin: A Properties Enhancement with Neutralized Phenolic-Resin and Resin Penetration into Wood Cell Walls. Wood Sci. Technol. 2004, 37, 349-361.

36. Biziks, V.; Bicke, S.; Militz, H. Penetration Depth of Phenol-Formaldehyde (PF) Resin into Beech Wood Studied by Light Microscopy. Wood Sci. Technol. 2019, 53, 165-176. [CrossRef]

37. Hu, L.; Pan, H.; Zhou, Y.; Zhang, M. Methods to Improve Lignin's Reactivity as a Phenol Substitute and as Replacement for Other Phenolic Compounds: A Brief Review. Bioresources 2011, 6, 3515-3525. [CrossRef]

38. Yang, S.; Wen, J.-L.; Yuan, T.-Q.; Sun, R.-C. Characterization and Phenolation of Biorefinery Technical Lignins for Lignin-PhenolFormaldehyde Resin Adhesive Synthesis. RSC Adv. 2014, 4, 57996-58004. [CrossRef]

39. Klašnja, B.; Kopitović, S. Lignin-Phenol-Formaldehyde Resins as Adhesives in the Production of Plywood. Holz Roh. Werkst. 1992, 50, 282-285. [CrossRef]

40. Tejado, A.; Kortaberria, G.; Peña, C.; Labidi, J.; Echeverría, J.M.; Mondragon, I. Lignins for Phenol Replacement in Novolac-Type Phenolic Formulations, Part I: Lignophenolic Resins Synthesis and Characterization. J. Appl. Polym. Sci. 2007, 106, $2313-2319$. [CrossRef]

41. Tejado, A.; Kortaberria, G.; Peña, C.; Blanco, M.; Labidi, J.; Echeverría, J.M.; Mondragon, I. Lignins for Phenol Replacement in Novolac-Type Phenolic Formulations. II. Flexural and Compressive Mechanical Properties. J. Appl. Polym. Sci. 2008, 107, 159-165. [CrossRef]

42. Jing, Z.; Lihong, H.; Bingchuan, L.; Caiying, B.; Puyou, J.; Yonghong, Z. Preparation and Characterization of Novolac PhenolFormaldehyde Resins with Enzymatic Hydrolysis Lignin. J. Taiwan Inst. Chem. Eng. 2015, 54, 178-182. [CrossRef]

43. Kalami, S.; Arefmanesh, M.; Master, E.; Nejad, M. Replacing 100\% of Phenol in Phenolic Adhesive Formulations with Lignin. J. Appl. Polym. Sci. 2017, 134, 45124. [CrossRef]

44. Luo, B.; Jia, Z.; Jiang, H.; Wang, S.; Min, D. Improving the Reactivity of Sugarcane Bagasse Kraft Lignin by a Combination of Fractionation and Phenolation for Phenol-Formaldehyde Adhesive Applications. Polymers 2020, 12, 1825. [CrossRef] [PubMed]

45. Lee, W.-J.; Chang, K.-C.; Tseng, I.-M. Properties of Phenol-Formaldehyde Resins Prepared from Phenol-Liquefied Lignin. J. Appl. Polym. Sci. 2011. [CrossRef]

46. Gao, S.; Cheng, Z.; Zhou, X.; Liu, Y.; Chen, R.; Wang, J.; Wang, C.; Chu, F.; Xu, F.; Zhang, D. Unexpected Role of Amphiphilic Lignosulfonate to Improve the Storage Stability of Urea Formaldehyde Resin and Its Application as Adhesives. Int. J. Biol. Macromol. 2020, 161, 755-762. [CrossRef] [PubMed]

47. Younesi-Kordkheili, H.; Pizzi, A.; Niyatzade, G. Reduction of Formaldehyde Emission from Particleboard by Phenolated Kraft Lignin. J. Adhes. 2016, 92, 485-497. [CrossRef]

48. Chen, Y.; Gong, X.; Yang, G.; Li, Q.; Zhou, N. Preparation and Characterization of a Nanolignin Phenol Formaldehyde Resin by Replacing Phenol Partially with Lignin Nanoparticles. RSC Adv. 2019, 9, 29255-29262. [CrossRef]

49. Gao, S.; Liu, Y.; Wang, C.; Chu, F.; Xu, F.; Zhang, D. Synthesis of Lignin-Based Polyacid Catalyst and Its Utilization to Improve Water Resistance of Urea-Formaldehyde Resins. Polymers 2020, 12, 175. [CrossRef] 
50. Yang, S.; Wu, J.-Q.; Zhang, Y.; Yuan, T.-Q.; Sun, R.-C. Preparation of Lignin-Phenol-Formaldehyde Resin Adhesive Based on Active Sites of Technical Lignin. J. Biobased Mat. Bioenergy 2015, 9, 266-272. [CrossRef]

51. Ghorbani, M.; Konnerth, J.; van Herwijnen, H.W.G.; Zinovyev, G.; Budjav, E.; Requejo Silva, A.; Liebner, F. Commercial Lignosulfonates from Different Sulfite Processes as Partial Phenol Replacement in PF Resole Resins. J. Appl. Polym. Sci. 2018, 135, 45893. [CrossRef]

52. Solt, P.; van Herwijnen, H.W.G.; Konnerth, J. Thermoplastic and Moisture-dependent Behavior of Lignin Phenol Formaldehyde Resins. J. Appl. Polym. Sci. 2019, 136, 48011. [CrossRef]

53. Kouisni, L.; Fang, Y.; Paleologou, M.; Ahvazi, B.; Hawari, J.; Zhang, Y.; Wang, X.-M. Kraft Lignin Recovery and Its Use in the Preparation of Lignin-Based Phenol Formaldehyde Resins for Plywood. Cellul. Chem. Technol. 2011, 45, 515-520.

54. Abdelwahab, N.A.; Nassar, M.A. Preparation, Optimisation and Characterisation of Lignin Phenol Formaldehyde Resin as Wood Adhesive. Pigment Resin Technol. 2011, 40, 169-174. [CrossRef]

55. Cheng, S.; Yuan, Z.; Leitch, M.; Anderson, M.; Xu, C.C. Highly Efficient Depolymerization of Organosolv Lignin Using a Catalytic Hydrothermal Process and Production of Phenolic Resins/Adhesives with the Depolymerized Lignin as a Substitute for Phenol at a High Substitution Ratio. Ind. Crop. Prod. 2013, 44, 315-322. [CrossRef]

56. Tachon, N.; Benjelloun-Mlayah, B.; Delmas, M. Organosolv Wheat Straw Lignin as a Phenol Substitute for Green Phenolic Resins. Bioresources 2016, 11, 5797-5815. [CrossRef]

57. Jin, Y.; Cheng, X.; Zheng, Z. Preparation and Characterization of Phenol-Formaldehyde Adhesives Modified with Enzymatic Hydrolysis Lignin. Bioresour. Technol. 2010, 101, 2046-2048. [CrossRef]

58. Qiao, W.; Li, S.; Guo, G.; Han, S.; Ren, S.; Ma, Y. Synthesis and Characterization of Phenol-Formaldehyde Resin Using Enzymatic Hydrolysis Lignin. J. Ind. Eng. Chem. 2015, 21, 1417-1422. [CrossRef]

59. Pang, B.; Cao, X.-F.; Sun, S.-N.; Wang, X.-L.; Wen, J.-L.; Lam, S.S.; Yuan, T.-Q.; Sun, R.-C. The Direct Transformation of Bioethanol Fermentation Residues for Production of High-Quality Resins. Green Chem. 2020, 22, 439-447. [CrossRef]

60. Cetin, N.S.; Ozmen, N. Use of Organosolv Lignin in Phenol-Formaldehyde Resins for Particleboard Production-I. Organosolv Lignin Modified Resins. Int. J. Adhes. Adhes. 2002, 22, 477-480. [CrossRef]

61. Khan, M.A.; Ashraf, S.M. Studies on Thermal Characterization of Lignin. J. Therm. Anal. Calorim. 2007, 89, 993-1000. [CrossRef]

62. Vázquez, G.; González, J.; Freire, S.; Antorrena, G. Effect of Chemical Modification of Lignin on the Gluebond Performance of Lignin-Phenolic Resins. Bioresour. Technol. 1997, 60, 191-198. [CrossRef]

63. Yang, W.; Rallini, M.; Natali, M.; Kenny, J.; Ma, P.; Dong, W.; Torre, L.; Puglia, D. Preparation and Properties of Adhesives Based on Phenolic Resin Containing Lignin Micro and Nanoparticles: A Comparative Study. Mater. Des. 2019, 161, 55-63. [CrossRef]

64. Ghorbani, M.; Konnerth, J.; Budjav, E.; Silva, A.; Zinovyev, G.; van Herwijnen, H.; Edler, M.; Griesser, T.; Liebner, F. Ammoxidized Fenton-Activated Pine Kraft Lignin Accelerates Synthesis and Curing of Resole Resins. Polymers 2017, 9, 43. [CrossRef] [PubMed]

65. Li, J.; Wang, W.; Zhang, S.; Gao, Q.; Zhang, W.; Li, J. Preparation and Characterization of Lignin Demethylated at Atmospheric Pressure and Its Application in Fast Curing Biobased Phenolic Resins. RSC Adv. 2016, 6, 67435-67443. [CrossRef]

66. Younesi-Kordkheili, H.; Pizzi, A. A Comparison between Lignin Modified by Ionic Liquids and Glyoxalated Lignin as Modifiers of Urea-Formaldehyde Resin. J. Adhes. 2017, 93, 1120-1130. [CrossRef]

67. Younesi-Kordkheili, H.; Pizzi, A.; Honarbakhsh-Raouf, A.; Nemati, F. The Effect of Soda Bagasse Lignin Modified by Ionic Liquids on Properties of the Urea-Formaldehyde Resin as a Wood Adhesive. J. Adhes. 2017, 93, 914-925. [CrossRef]

68. Younesi-Kordkheili, H.; Pizzi, A.; Mohammadghasemipour, A. Improving the Properties of Ionic Liquid-Treated Lignin-UreaFormaldehyde Resins by a Small Addition of Isocyanate for Wood Adhesive. J. Adhes. 2018, 94, 406-419. [CrossRef]

69. Younesi-Kordkheili, H. Improving Physical and Mechanical Properties of New Lignin-Urea-Glyoxal Resin by Nanoclay. Eur. J. Wood Prod. 2017, 75, 885-891. [CrossRef]

70. Younesi-Kordkheili, H.; Pizzi, A. Improving the Properties of Urea-Lignin-Glyoxal Resin as a Wood Adhesive by Small Addition of Epoxy. Int. J. Adhes. Adhes. 2020, 102, 102681. [CrossRef]

71. Younesi-Kordkheili, H.; Pizzi, A. Some of Physical and Mechanical Properties of Particleboard Panels Bonded with Phenol-LigninGlyoxal Resin. J. Adhes. 2020, 96, 1385-1395. [CrossRef]

72. Younesi-Kordkheili, H.Y.; Pizzi, A. Improving Properties of Phenol-Lignin-Glyoxal Resin as a Wood Adhesive by an Epoxy Resin. Eur. J. Wood Prod. 2021, 79, 199-205. [CrossRef]

73. Zhang, Y.; Li, N.; Chen, Z.; Ding, C.; Zheng, Q.; Xu, J.; Meng, Q. Synthesis of High-Water-Resistance Lignin-Phenol Resin Adhesive with Furfural as a Crosslinking Agent. Polymers 2020, 12, 2805. [CrossRef] [PubMed]

74. Chen, Y.; Fu, S.; Zhang, H. Signally Improvement of Polyurethane Adhesive with Hydroxy-Enriched Lignin from Bagasse. Colloids Surf. A Physicochem. Eng. Asp. 2020, 585, 124164. [CrossRef]

75. Liu, W.; Fang, C.; Chen, F.; Qiu, X. Strong, Reusable, and Self-Healing Lignin-Containing Polyurea Adhesives. ChemSusChem 2020, 13. [CrossRef]

76. Yuan, Y.; Guo, M.H.; Liu, F.Y. Preparation and Evaluation of Green Composites Using Modified Ammonium Lignosulfonate and Polyethylenimine as a Binder. Bioresources 2013, 9, 836-848. [CrossRef]

77. Raj, A.; Devendra, L.P.; Sukumaran, R.K. Comparative Evaluation of Laccase Mediated Oxidized and Unoxidized Lignin of Sugarcane Bagasse for the Synthesis of Lignin-Based Formaldehyde Resin. Ind. Crop. Prod. 2020, 150, 112385. [CrossRef]

78. Marciano, S.J.; Avelino, F.; da Silva, L.R.R.; Mazzetto, S.E.; Lomonaco, D. Microwave-Assisted Phosphorylation of Organosolv Lignin: New Bio-Additives for Improvement of Epoxy Resins Performance. Biomass Conv. Bioref. 2020. [CrossRef] 
79. Liang, X.; Hu, Q.; Wang, X.; Li, L.; Dong, Y.; Sun, C.; Hu, C.; Gu, X. Thermal Kinetics of a Lignin-Based Flame Retardant. Polymers 2020, 12, 2123. [CrossRef]

80. Biziks, V.; Fleckenstein, M.; Mai, C.; Militz, H. Suitability of a Lignin-Derived Mono-Phenol Mimic to Replace Phenol in Phenol-Formaldehyde Resin for Use in Wood Treatment. Holzforschung 2020, 74, 344-350. [CrossRef]

81. Nakos, P.; Tsiantzi, S.; Athanassiadou, E. Wood Adhesives Made with Pyrolysis Oils. ACM Wood Chem. Plc 2001, 1-8.

82. Dier, T.K.F.; Fleckenstein, M.; Militz, H.; Volmer, D.A. Exploring the Potential of High Resolution Mass Spectrometry for the Investigation of Lignin-Derived Phenol Substitutes in Phenolic Resin Syntheses. Anal. Bioanal. Chem. 2017, 409, 3441-3451. [CrossRef]

83. Farag, S.; Chaouki, J. Economics Evaluation for On-Site Pyrolysis of Kraft Lignin to Value-Added Chemicals. Bioresour. Technol. 2015, 175, 254-261. [CrossRef] [PubMed]

84. Di, B.; Li, Z.; Lei, Y.; Wang, X.; Zhu, Y.; Qi, W.; Tian, Y. Phenol-enriched Hydroxy Depolymerized Lignin by Microwave Alkali Catalysis to Prepare High-adhesive Biomass Composites. Polym. Eng. Sci. 2021, pen.25664. [CrossRef]

85. Solt, P.; Rößiger, B.; Konnerth, J.; van Herwijnen, H. Lignin Phenol Formaldehyde Resoles Using Base-Catalysed Depolymerized Kraft Lignin. Polymers 2018, 10, 1162. [CrossRef] [PubMed]

86. Czernik, S.; Bridgwater, A.V. Overview of Applications of Biomass Fast Pyrolysis Oil. Energy Fuels 2004, 18, 590-598. [CrossRef]

87. Roy, C.; Lu, X.; Pakdel, H. Process for the Production of Phenolic-Rich Pyrolysis Oils for Use in Making Phenol-Formaldehyde Resole Resins. U.S. Patent No. 6,143,856, 7 November 2000.

88. Chan, F.; Riedl, B.; Wang, X.-M.; Lu, X.; Ame-Chen, C.; Roy, C. Performance of Pyrolysis Oil-Based Wood Adhesives in OSB. For. Prod. J. 2002, 52, 31-38.

89. Zabelkin, S.; Valeeva, A.; Sabirzyanova, A.; Grachev, A.; Bashkirov, V. Neutrals Influence on the Water Resistance Coefficient of Phenol-Formaldehyde Resin Modified by Wood Pyrolysis Liquid Products. Biomass Conv. Bioref. 2020. [CrossRef]

90. Sukhbaatar, B.; Steele, P.H.; Kim, M.G. Use of Lignin Separated Form Bio-Oil in Oriented Strand Board Bilder PhenolFormaldehyde Resins. Bioresources 2009, 4, 789-804.

91. Celikbag, Y.; Nuruddin, M.; Biswas, M.; Asafu-Adjaye, O.; Via, B.K. Bio-Oil-Based Phenol-Formaldehyde Resin: Comparison of Weight- and Molar-Based Substitution of Phenol with Bio-Oil. J. Adhes. Sci. Technol. 2020, 2743-2754. [CrossRef]

92. Dessbesell, L.; Yuan, Z.; Hamilton, S.; Leitch, M.; Pulkki, R.; Xu, C.C. Bio-Based Polymers Production in a Kraft Lignin Biorefinery: Techno-Economic Assessment: Bio-Based Polymer Production in a Kraft Lignin Biorefinery. Biofuels Bioprod. Bioref. 2018, 12, 239-250. [CrossRef]

93. Xu, C.C.; Dessbesell, L.; Zhang, Y.; Yuan, Z. Lignin Valorization beyond Energy Use: Has Lignin's Time Finally Come? Biofuels Bioprod. Bioref. 2020, 15, 32-36. [CrossRef]

94. van Herwijnen, H.W.G.; Fliedner, E.; Heep, W. Verwendung nachwachsender Rohstoffe in Bindemitteln für Holzwerkstoffe. Chem. Ing. Tech. 2010, 82, 1161-1168. [CrossRef]

95. Schröder, I. Prefere Resins Germany GmbH Konsolidierte Umwelterklärung 2019 EG-VO Nr. 1221/2009 (EMAS III); Prefere Resins Germany GmbH: Erkner, Germany, 2019.

96. UPM Biochemicals GmbH Bahnbrechende Entwicklungen in der LIGNIN Wertschöpfungskette. Available online: https:/ www. upm.com/de/neuigkeiten-und-artikel/articles/2019/11/bahnbrechende-entwicklungen-in-der-lignin-wertschopfungskette/ (accessed on 16 March 2021).

97. Borregaard LignoTech Binding Agent. Available online: https://www.lignotech.com/Product-Functionalities/Binding-Agent (accessed on 16 March 2021).

98. Kruus, K.; Hakala, T. The Making of Bioeconomy Transformation; VTT Technical Research Centre of Finland: Espoo, Finland, 2017; ISBN 978-951-38-8503-8.

99. HEXION Hexion-Canadian Partnership for Bio-Based Resins. Available online: https://www.hexion.com/en-us/catalyst/ catalyst-blog/2020/05/21/hexion-canadian-partnership-for-bio-based-resins (accessed on 19 March 2021).

100. Klabin, S.A. Klabin Acquires Technology for Extracting Lignin at Pilot Mill Complex. Available online: https://klabin.com.br/ en/newsroom/press-release/klabin-acquires-technology-for-extracting-lignin-at-pilot-mill-complex/ (accessed on 19 March 2021).

101. Lettner, M.; Hesser, F.; Hedeler, B.; Schwarzbauer, P.; Stern, T. Barriers and Incentives for the Use of Lignin-Based Resins: Results of a Comparative Importance Performance Analysis. J. Clean. Prod. 2020, 256, 120520. [CrossRef]

102. Wallmo, H.; Karlsson, H.; Littorin, A. Lignin Production Upgraded_Industry-Specific Qualities to Broaden the Commercial Potential; 2020.

103. Chum, H.L.; Black, S.K. Process for Fractionating Fast-Pyrolysis Oils, and Products Derived Therefrom. U.S. Patent No. 4,942,269, 17 July 1990.

104. McFarlaine, H.M. Resins from Spent Sulphite Liquor. CA. Patent No. 696,732, 17 October 1964.

105. Pecina, H.; Wienhaus, O.; Kühne, G.; Bernaczyk, Z.; Lubisch, H.-J.; Sauer, J.-D. Verfahren zur Herstellung eines Bindemittels auf Ligninbasis. D.D. Patent No. 297,898, 17 October 1983.

106. Wennerblom, B.A.; Karlsson, A.H. Verfahren zur Herstellung von Ligninharz. DE. Patent No. 2,408,441, 21 February 1973.

107. Wallace, F.J. Manufacture of Resins from Lignin. U.S. Patent No. 2,209,289, 23 July 1940.

108. Read, D.W. Process for Producing Desulfonated Lignin Resins. U.S. Patent No. 3,551,405, 29 December 1970.

109. Schneider, M.H.; Phillips, J.G. Furfuryl Alcohol and Lignin Adhesive Composition. U.S. Patent No. 6,747,076, 8 June 2004. 
110. Lettner, M.; Solt, P.; Rößiger, B.; Pufky-Heinrich, D.; Jääskeläinen, A.-S.; Schwarzbauer, P.; Hesser, F. From Wood to ResinIdentifying Sustainability Levers through Hotspotting Lignin Valorisation Pathways. Sustainability 2018, 10, 2745. [CrossRef]

111. Yuan, Y.; Guo, M. Do Green Wooden Composites Using Lignin-Based Binder Have Environmentally Benign Alternatives? A Preliminary LCA Case Study in China. Int. J. Life Cycle Assess. 2017, 22, 1318-1326. [CrossRef]

112. Hildebrandt, J.; Budzinski, M.; Nitzsche, R.; Weber, A.; Krombholz, A.; Thrän, D.; Bezama, A. Assessing the Technical and Environmental Performance of Wood-Based Fiber Laminates with Lignin Based Phenolic Resin Systems. Resour. Conserv. Recycl. 2019, 141, 455-464. [CrossRef] 